\title{
Trade Policy as Well as Non Trade Policy Reforms and Export Performance of Agricultural Commodities: An Empirical View of Developing Countries
}

\author{
Tomson Odongo \\ Department of Finance, Makerere University Business School, Kampala, Uganda \\ Email address: \\ tsodongo@yahoo.com \\ To cite this article: \\ Tomson Odongo. Trade Policy as Well as Non Trade Policy Reforms and Export Performance of Agricultural Commodities: An Empirical \\ View of Developing Countries. International Journal of Economic Behavior and Organization. Vol. 3, No. 4, 2015, pp. 65-68. \\ doi: 10.11648/j.ijebo.20150304.12
}

\begin{abstract}
This paper reviews relevant literatures to provide an empirical view on the role of trade policy as well as non trade policy reforms on export performance of agricultural commodities from developing countries during the 1990s and the subsequent years. The study discovered that trade policy reforms introduced to developing countries during the 1990 are central in determining output and consequently export performance of agricultural commodities. The study recommends for promotion of trade policy reforms within agricultural sector in developing countries in order to promote export performance of agricultural commodities.
\end{abstract}

Keywords: Trade Policy, Non Trade Policy Reforms, Export Performance of Agricultural Commodities

\section{Introduction}

In the early years of 1990s, some developing countries sought to raise export by revamping productive structures of their economies. Other countries on the other hand aimed at improving export capabilities of their economies by liberalization of international trade and payments (Greenaway, Wyn and Wright, 2002). Trade liberalization was introduced to developing countries to promote export by increasing sensitivity of export to price changes in the world market (Thirlwall, 2000). In the period following trade liberalization, domestic exports from developing countries were expected to be stimulated by high and rising international prices (Ssemogerere and Kasekende, 1994).

\section{Trade Policy Reforms and Export Performance of Agricultural Commodities}

Several studies have underscored the role of trade policy reforms to export performance of agricultural commodities from developing countries during the 1990s. Some of these studies argue that the demand for export of agricultural commodities from developing countries is in response of trade liberalization, with elasticity of demand ranging between -3 and -6 percent (Kusi, 2002) and (Imad, Elfadil, Abdel and Izdihar, 2007).

Other scholars on the other hand, present elasticity of supply of agricultural commodities from developing countries as generally about 1 percent, for some countries it is as low as 0.35 percent (Behar and Lawrence, 2004). The low performance of elasticity of supply of agricultural commodities from developing countries is due to supply rigidities in these countries. The supply rigidities in developing countries are characterized by political instabilities, poor infrastructure development, poor weather conditions and inappropriate macroeconomics policies.

Owing to supply rigidities in developing countries, several incentives have been introduced to these countries to improve on the supply of agricultural commodities. Price stabilization scheme is one of such incentives (Prina, 2007). It was introduced to developing countries during the 1980s to encourage production of agricultural commodities even when world market price was low.

The importance of price system to export performance of agricultural commodities is not a recent phenomenon in economic literature. It has been central in contemporary research since 1958 when Nerlove developed a study on the supply response of farm products to price changes in 
American market. So far, there has been growing conflicting evidence ranging from low price elasticity to lack of responsiveness depending on the region, the country, the crop and the level of aggregation.

In the recent years, it has been confirmed by some scholars that the supply of traditional and nontraditional cash crops from developing countries are in response of price incentives introduced to these countries following the economics and the structural reforms of 1990s. According to Kihangire and Apaa (2007), cotton farmers in Uganda are responsive to price incentives introduced to the country following liberalization of the cotton industry in the 1990s.

Some scholars on the other hand, argue that increase in international prices of agricultural commodities exported from developing countries can not determine export capabilities of these countries. According to Mold and Prizzon (2008), the volumes of export commodities from non oil exporting countries of Africa increased significantly during the 1990s, despite being confronted with sharp declining prices. Gbetnkom and Khan (2002) support the above observation but recommend for adoption of trade liberalization policy in agricultural sector in developing countries in order to drive positive movements in the export sector.

Regardless of the above observations, Ashfaq, Sheikh and Akmal (2010) present mix results while investigating determinants of export performance of agricultural commodities from Pakistan. Whereas increase in international prices of wheat and maize were indicated ineffective in promoting export performance of these commodities, it is far more effective among rice producing farmers.

Despite the mix results indicated above, other scholars argue that increase in international prices of agricultural commodities exported from developing countries has been in response of trade policy reforms introduced to these countries during the 1990s. According to Blake, Mckay and Morrissey (2001), there has been significant gain in the export of agricultural commodities from Uganda due to trade liberalization program introduced to the country during the 1990s.

Thirlwall (2000) confirms the above observation while investigating the effect of trade liberalization on economic growth of a sample of developing countries during the 1990s. The major finding in this study is that trade liberalization encourages massive growth in world trade relative to world output. Berges (2007), supports the above observation but further indicates that trade liberalization promotes exports of agricultural commodities between developed and developing countries.

Beside the above observations, Santos-Paulino (2000) presents multiple findings while investigating the effect of trade liberalization on export performance of agricultural commodities from a sample of developing countries during the 1990s. The major findings in the study are that trade liberalization promotes exports of agricultural commodities from developing countries but changes in relative prices of the export commodities are negatively related to export growth, while exports are positively related to world income growth and export duties have detrimental effect on export growth.

Other scholars on the other hand, believe that changes in relative prices of agricultural commodities exported from Sub-Saharan African countries do not contribute significant effect on export performance of these commodities. In particular, changes in real exchange rate were found ineffective in stimulating export performance of agricultural commodities from Uganda during the 1990s (Ssemogerere and Kasekende, 1994). This performance implies that exchange rate policies pursued by some developing countries during this period never enlisted significant gains among export producers.

Despite the dismal performance in the export sector due to exchange rate policies mentioned above, the dual effect of trade liberalization and privatization policies introduced to developing countries during the 1990 s can to some extent stimulate export performance of agricultural commodities. Mwase (1998) examined this effect while analyzing performance of cashewnut industry in Tanzania. The major finding in this study is that trade liberalization and privatization policies introduced to this country during the 1990s stimulated significant performance in pricing, marketing and processing policies of agricultural commodities.

The above performance has been deeply felt by private firms and traders other than public firms. Secondly, not only has trade liberalization contributed significant effect on export performance of agricultural commodities from Sub Saharan African countries, it is also instrumental in other developing countries of Asia and Latin America (SantosPaulino, 2003) and (Thirlwall, 2004).

Sharma (2006) not only confirms the above observation but further recommends for adoption of favorable infrastructural policy reforms in agricultural sector in developing countries, alongside trade liberalization in order to promote export performance of agricultural commodities.

\section{Non Trade Policy Reforms and Export Performance of Agricultural Commodities}

Despite the role of trade policy reforms on export performance of agricultural commodities from developing countries during the 1990s, increase the share of world market price received by the local export producers is an important incentive that can drive positive movements in the export sector (Baffes, 2002). This is because a rising share of world market price received by the local export producers can drive positive movements in export producing capabilities of developing countries.

Accordingly, trade liberalization, privatization as well as pricing policies adopted by some developing countries during the 1990s can not stimulate significant effect on 
export performance of agricultural commodities from developing countries without having had effect on the share of world market price received by the local export producers.

Despite the several reforms mentioned above, there is need for complementary policies in developing countries, alongside trade liberalization, privatization and pricing policies to support production and export of agricultural commodities. Some of these policies include; efficient credit system, as well as improved input production and distribution (Goreux and Macrae, 2003).

Secondly, there is need for practical effort on the ground to directly or indirectly address the poor performance of export commodities. The absence of such effort is perhaps due to lack of commitment by policy makers and politicians in developing countries to initiate policies that can drive positive movements in the export sector.

Another factor that can drive positive movements in export performance of agricultural commodities from developing countries is the increase in trading partners' income (Prasad, 2000). This is particularly true during economic boom. During recession however, trading partners' incomes certainly fall, follows by fall in imports. In the short run however, export supplies are driven by policies that can eliminate supply side constraints. The supply side constraints in developing countries are characterized by high cost of production, exchange rate misalignment, poor development of infrastructure as well as unskilled labor supply (Lawrence and Phil, 2005).

In contrast to the supply side constraints mentioned above, there is need for developing countries to further improve on transport infrastructure, economic integration, macroeconomic soundness and institutional capacity utilization in order to drive positive movements in the export sector (Fugazza, 2004).

The role of internal production policies in developing countries is central in promoting export performance of agricultural commodities. Reliable internal production policies in developing countries are characterized by institutional capability building. In particular, China's export growth in the period between 1992 and 2001 is practical evidence that emanates from the country's internal production policies which attracted quite a huge number of Foreign Direct Investments (FDIs) in to the country (Wu, 2003). Land locked countries with little access to seaports however need to have strong infrastructural policies in place in order to attract FDIs in to their countries (Redding and Venables, 2003).

For the last two decades, Latin America's export performance has been associated with internal supply conditions. The internal supply conditions in developing countries are characterized by improvements in infrastructure, better methods of production and availability of cheap labor. The recent sluggish growth in the Latin America's economies is perhaps due to China's expansion in to the global market and inability of Latin America's countries to make the necessary economic reforms that can drive positive movements in the export sector (Hanson and Robertson,
2006).

One other important internal production policy that can drive positive movements in the export performance of agricultural commodities from developing countries is good governance. Zimbabwean's economic performance in the recent past is an important clue to this effect. The country witnessed high level of ethnic tension coupled with poor governance as well as parallel market condition that led to low output and consequently poor export performance (Munoz, 2006).

Despite significant contributions of trade policy reforms to export performance of agricultural commodities from developing countries during the 1990s, there is need for technological reforms in agricultural sector in these countries to drive positive movements in the export sector. The technological reforms in agricultural sector in developing countries are characterized by massive integration of technological changes reminiscent of improved seeds, greater use of agrochemical, machinery and agronomic technologies (Pineiro, 2006). The trade policy reforms indicated by trade liberalization, privatization, pricing policies as well as deregulation of fiscal and monetary policies introduced to developing countries during the 1990s can as well motivate adoption of better technologies in agricultural sector in these countries.

\section{Concluding Remark}

This paper reviews relevant literatures to present an empirical view on the role of trade policy as well as non trade policy reforms on export performance of agricultural commodities from developing countries during the 1990s and the subsequent years. Whereas Pineiro (2006), Munoz (2006), Hanson and Robertson (2006), Redding and Venables (2003), Wu (2003) and Fugazza (2004) argue that non trade policy reforms carried out in developing countries during the 1990 s were central in promoting export performance of agricultural commodities; nevertheless, the trade policy reforms introduced to these countries during this period are central in determining output and consequently export performance of agricultural commodities (Santos-Paulino and Thirlwall, 2004), (Kusi, 2002), (Greenaway, Wyn and Wright, 2002), (Thirlwall, 2000) and (Imad, Elfadil, Abdel and Izdihar, 2007).

\section{Policy Implication}

The study recommends for promotion of trade policy reforms within agricultural sector in developing countries in order to promote export performance of agricultural commodities.

\section{References}

[1] Ashfaq M., Sheikh A.D. and Akmal N., (2010). Impact of Trade Liberalization on Agriculture in Pakistan; Journal of Agriculture 2010 48(10). 
[2] Baffes J., (2002). Tanzania's cotton sector's constraint and challenges in a Global Environment, Published by World Bank ABNB000654VCY.

[3] Behar A. and Lawrence E., (2004). Estimating elasticity of demand and supply for South Africa manufactured exports using Vector Error Correction Mechanism

[4] Berges A. R., (2007). Trade Liberalization and Market Access: Analyzing Dominican Export Performance during Twentieth Century. Working Paper No. 61 St. Anthony College.

[5] Fugazza, (2004). Overview of Export Performance of New Europe.

[6] Gbetnkom D. and Khan S., (2002). Determinants of Agricultural Exports: The case of Cameroon (AERC Research Paper 120).

[7] Goreux L. and Macrae J., (2003). Reforming the Cotton Sector in Sub- Sahara Africa (SSA). African Region Series Working paper No. 047.

[8] Greenaway D., Wyn M. and Wright P., (2002). Trade Liberalization and Growth in Developing Countries. Journal of Development Economics Volume 67(2002) pages 229 to 244.

[9] Imad E., Elfadil A., Karim Y. and Izdihar A., (2007). The Impact of Domestic and Trade Policies on Sudan's Agricultural Export Earnings.

[10] Kihangire D. and Apaa O., (2007). Agricultural and supply response in Uganda: An examination of aggregate, Traditional and Non Traditional Export Crops. Bank of Uganda Working Paper /07/08.

[11] Kusi N. K., (2002). Trade Liberalization and South Africa's Export Performance. Trade and Industrial Policy Strategies (TIPS) 2002 Annual Forum.

[12] Lawrence E. and Phil A., (2005). South African Exports Performance: Determinants of Exports Supply. Africa region working paper series No. 95.

[13] Mold A. and Pizzon A., (2008). Explaining Africa's Recent Export Performance and Limited Gains from the Commodity Boom.

[14] Munoz S., (2006). Zimbabwe's Export performance: The impact of the parallel market and Governance factor International Monetary Fund (IMF) WP/06/28.

[15] Mwase N., (1998). Economic Liberalization and Privatization of Agricultural Marketing and input supply in Tanzania: A case study of Cashew nuts. African Economics Research Consortium 1998.

[16] Pineiro V., (2006). The impact of Trade Liberalization and Policy Liberalization on Argentina's agricultural sector: Technology adoption in a Dynamic Model. A PhD Dissertation, University of Maryland (College Park, Md.).

[17] Prasad S., (2000). Determinants of Exports in Fiji. Working Paper 2000/04 Economics Department Reserve Bank of Fiji.

[18] Prina S., (2007). Agricultural Trade liberalization in Mexico: Impact on boarder prices and Farmers' Income. Journal Article.

[19] Redding S. and Venables A., (2003). Geography and Export Performance - External Market Access and Internal Supply Capacity. CEPR; Discussion paper 3807.

[20] Santos-Paulino A., (2000). Trade Liberalization and Exports Performance in Selected Developing Countries. University of Kent June 2000. Available at ftp://ftp.ukc.ac.uk/pub/ejr/RePEc/ukc/ukcedp/ 0012.pdf.

[21] Santos-Paulino A., (2003). Trade Liberalization and Export Performance in the Dominican Republic. University of Kent June 2003.

[22] Sharma K. L., ((2006). High Value Agricultural Products of the Fiji Island Performance and Prospects. The University of the South Pacific- Suva Fiji Island.

[23] Ssemogerere G. N. and Kasekende L. A., (1994). Constraint to Development and Diversification of nontraditional exports in Uganda, 1981-1990. African Economic Research Consortium. pp 47- 48.

[24] Thirlwall A. P., (2000). Trade Liberalization and Economic Growth: Theory and Evidence, African Development Review. ECONOMIC RESEARCH PAPERS NO 63 Copyright C 2000, The African Development Bank 01 B.P. 1387 Abidjan 01 Côte d'Ivoire. Available at www.afdb.org/fileadmin uploads/afdb/.../00157660-FR-ERP-63.PDF.

[25] Thirlwall A. P., (2004). Trade, the Balance of Payments and Exchange Rate Policy in Developing Countries, $26^{\text {th }}$ May. Edward Elgar Pub. ISBN 10 1843768488/1-84376-848-8. Available at: www.eelgar.co.uk/bookentry_main.lasso?id=2957.

[26] Wu F., (2003). Foreign Direct Investment to China and Southern Asia: Has Asia been losing out? A journal of Asian Business. 